\title{
CHS2, a chitin synthase gene from the oomycete Saprolegnia monoica
}

\author{
Maryline Mort-Bontemps, Lucien Gay and Michel Fèvre
}

Author for correspondence: Michel Fèvre. Tel: +330472448378 . Fax: + 330472431181. e-mail: mfevre@biomserv.univ-lyon1.fr

Laboratoire de Biologie Cellulaire Fongique, Centre de Génétique Moléculaire et Cellulaire, UMR CNRS 5534 Université Lyon I, $43 \mathrm{Bd}$ du

11 Novembre 1918

Bâtiment 405,69622

Villeurbanne Cedex, France

\begin{abstract}
PCR was used to amplify fragments corresponding to the chitin synthase (CHS) genes from the Oomycetes Saprolegnia monoica, Phytophthora capsici and Achlya ambisexualis, utilizing as primers, oligonucleotides designed from the conserved region of CHS genes of chitinous fungi. Chitin synthase homologues were found in the three cellulosic fungi. The chitin synthase 2 gene (CHS2) from 5 . monoica was cloned, sequenced and characterized. The amino acid sequence deduced from the CHS2 genomic DNA revealed several domains, corresponding to the catalytic domains and polypeptide signatures, of high identity with CHS genes from chitinous fungi. Existence of a CHS gene family in S. monoica was supported by the identification of two CHS sequences among the PCR products, the localization of CHS homologues on two chromosomes, and the detection of two transcripts in mycelia and protoplasts. Polyclonal anti-chitin synthase antibodies raised against the $\mathbf{N}$-terminal and the neutral fragments of the CHS2 products revealed, respectively, two and four proteins in membrane fractions and a truncated active form in entrapped product. The overall comparison of the structure and organization of CHS genes indicates that in spite of their divergent evolution, Oomycetes and chitinous fungi have evolved with conserved chitin synthase systems.
\end{abstract}

Keywords: Saprolegnia monoica, Oomycetes, cell wall, chitin synthases, immunodetection

\section{INTRODUCTION}

In filamentous fungi, chitin is the supporting component of the cell wall while, in yeasts, it is a relatively minor component used to maintain the structure of the mother bud junction.

Chitin synthases have been characterized from a wide range of fungal species (Cabib, 1987; Bartnicki-Garcia et al., 1978). Most preparations are zymogenic, that is, they are produced as inactive proenzymes that are activated by proteases, but so far, no chitin synthase polypeptides have been purified to homogeneity. The genetics and molecular biology of chitin synthase are providing increasing information (for a review see Bulawa, 1993). Three chitin synthase genes of Saccharomyces cerevisiae have been characterized. Two of them, CHS1 and CHS2 encode protease-activated zymogen

\footnotetext{
Abbreviation: RT-PCR, reverse transcriptase polymerase chain reaction. The GenBank/EMBL accession number of the nucleotide sequence reported in this paper is U19946.
}

while CHS3, encoded by CAL1/CDS2, does not require proteolytic activation. Their roles have been studied in gene disruption experiments. Each chitin synthase has a different role in yeast morphogenesis: CHS3 is involved in the formation of the chitin ring during budding, CHS2 catalyses the formation of the central layer of the primary septum (Shaw et al., 1991), and CHS1 acts as a repair enzyme (Cabib et al., 1989).

The analyses of chitin synthase genes of filamentous fungi have not been as comprehensive as in yeast. Conserved regions of $\mathrm{CHS}$ genes from several filamentous fungi have been sequenced, establishing the widespread distribution of the enzymes in chitinous fungi (Bowen, 1992; Mehmann et al., 1994). Analysis of DNA fragments from taxonomically diverse fungal species have shown that most fungi have three to six chitin synthase genes (Mellado et al., 1995; Din et al., 1996; Karuppayil et al., 1995). However, there is little information on the function of the gene products during growth of filamentous fungi. Inactivation of Neurospora crassa chs1 and of Aspergillus nidulans chsB induced morphological abnormalities of the hyphae (Yarden \& 
Yanofsky, 1991; Yanai et al., 1994). In contrast, there was no apparent morphological consequence of the inactivation of $N$. crassa chs $2, A$. nidulans chs $A$ and Ustilago maydis chs1 and chs 2 as the mutants retained the wild-type morphology (Din \& Yarden, 1994; Yanai et al., 1994; Gold \& Kronstadt, 1994; XoconostleCazares et al., 1996). These results suggest that redundant genes must exist.

Fungi have been subdivided into categories based on dual combination of the principal cell wall polymers. Oomycetes were classified as a cellulose-glucan group while higher fungi were considered as chitin-glucan groups (Bartnicki-Garcia, 1968). The Oomycetes have been grouped with the true fungi but comparison of several biochemical and morphological characteristics and molecular analyses indicate that the fungi are polyphyletic (Cavalier-Smith, 1987; Gunderson et al., 1987; Barr, 1992). Oomycetes can be considered as pseudofungi that have evolved from heterokont algae (Cavalier-Smith, 1986). Saprolegnia monoica, which belongs to the class Oomycetes, has been traditionally regarded as a cellulosic fungus. In a previous report, we demonstrated the presence of chitin in the cell wall of $S$. monoica by chemical extraction of the polymer and its identification by X-ray and electron diffraction patterns and infrared spectroscopy (Bulone et al., 1992). Like enzymes from chitinous fungi, solubilized chitin synthase from $S$. monoica is zymogenic, activated by trypsin and catalyses in vitro synthesis of spindle-like crystals (Gay et al., 1992, 1993).

The aim of the present study was to undertake a detailed characterization of chitin-synthase-encoding genes from this cellulosic pseudofungus, to compare them to corresponding genes from true fungi and to extend the comparison of the chitin synthase system between cellulosic and chitinous fungi. We report the presence of two CHS genes in S. monoica, their localization on two chromosomes, the isolation of a CHS gene, its nucleotide sequence and the occurrence of CHS genes in two other Oomycetes, Achlya ambisexualis and Phytophthora capsici. Polyclonal antibodies, raised against a recombinant truncated Chs 2 protein, revealed more than one protein of high molecular mass, confirming the presence of a CHS gene family in this cellulosic fungus.

\section{METHODS}

Strains. Saprolegnia monoica Pringsheim no. 53967 Dick, obtained from CBS Baarn, The Netherlands, and Phytophthora capsici, obtained from Dr P. Nodet (University of Brest, France), were routinely grown on potato dextrose agar (PDA). Liquid cultures were grown in Petri dishes containing $100 \mathrm{ml}$ liquid medium (Machlis, 1953) inoculated with mycelial disks cut from the margins of 4-d-old colonies.

Cloning strategy. Oligonucleotides corresponding to the conserved regions of CHS from yeasts, designed by Bowen $e t$ al. (1992), were synthesized and used as primers for PCR (Table 1). PCR amplification of genomic DNA was carried out in $100 \mu \mathrm{l}$ volumes, containing $1 \mathrm{U}$ Taq DNA polymerase, $50 \mu \mathrm{M}$ of each dNTP, $50 \mathrm{mM}$ Tris $/ \mathrm{HCl} \mathrm{pH} \mathrm{9.0,16} \mathrm{mM}$ $\left(\mathrm{NH}_{4}\right)_{2} \mathrm{SO}_{4}, 50 \mathrm{mM} \mathrm{KCl}, 7 \mathrm{mM} \mathrm{MgCl}_{2}, 0 \cdot 2 \mathrm{mg} \mathrm{BSA} \mathrm{ml}{ }^{-1}$,
$200 \mathrm{ng}$ genomic DNA and $100 \mathrm{pmol}$ of each primer. Thirtyfive cycles of PCR were done on the genomic DNA with denaturing at $94{ }^{\circ} \mathrm{C}$ for $1 \mathrm{~min}$, annealing at $50^{\circ} \mathrm{C}$ for $1 \mathrm{~min}$ and extension at $72{ }^{\circ} \mathrm{C}$ for $3 \mathrm{~min}$, followed by one final cycle at $72{ }^{\circ} \mathrm{C}$ for $10 \mathrm{~min}$. The PCR products were analysed by electrophoresis on $1.5 \%(\mathrm{w} / \mathrm{v})$ agarose gels and visualized by UV transillumination after staining with ethidium bromide. The PCR bands were excised, purified with glass milk and subcloned into the pUC18 vector using the HindIII and SalI restriction sites engineered at the end of the primers. A genomic library of $S$. monoica constructed in the phage $\lambda$ EMBL3 (V. Bulone, unpublished) was screened using as a probe the CHS2 PCR product labelled by random priming. Positive clones were purified and amplified. Fragments of the insert were subcloned in pUC18 for further analysis.

Nucleotide sequences were determined using the dideoxy chain-termination method (Sanger et al., 1977) on doublestranded DNA using either universal primers or oligonucleotide primers to yield complete sequences from both strands.

Nucleic acid isolation and hybridization. DNA from $S$ monoica and from P. capsici was isolated according to the procedure of Raeder \& Broda (1985). Southern hybridizations using Hybond-N membranes (Amersham) were as described by Sambrook et al. (1989). Total RNA was extracted by the acid guanidine thiocyanate procedure (Chirgwin et al., 1979). RNA was separated in formaldehyde/agarose gels, transferred to Hybond-N + membranes (Amersham) and hybridized with the radiolabelled probe (Sambrook et al., 1989).

RT-PCR. Detection of RNA transcripts was carried out using reverse-transcriptase polymerase chain reaction (RT-PCR) (Shuldiner et al., 1991). The first strand cDNA synthesis reactions (RT reaction) were performed on $1 \mu \mathrm{g}$ denatured RNA which had been treated with DNase I (Boehringer Mannheim) in the presence of $1 \mathrm{M}$ sodium acetate and $10 \mathrm{mM}$ $\mathrm{MgSO}_{4}$ for $4 \mathrm{~h}$ at $37^{\circ} \mathrm{C}$. The RNA was mixed with $1 \mathrm{mM}$ of each dNTP, 20 U RNasin Ribonuclease Inhibitor (Promega), $50 \mathrm{mM} \mathrm{KCl}, 20 \mathrm{mM}$ Tris/ $\mathrm{HCl} \mathrm{pH} \mathrm{8.4,} 2.5 \mathrm{mM} \mathrm{MgCl}, 1 \mathrm{mg}$ BSA ml ${ }^{-1}, 100 \mathrm{pmol}$ oligonucleotide-3' and $200 \mathrm{U}$ Moloney Murine Leukemia Virus (MMLV)-Reverse Transcriptase (Promega), and incubated at $37^{\circ} \mathrm{C}$ for $60 \mathrm{~min}$ followed by a $10 \mathrm{~min}$ incubation at $95^{\circ} \mathrm{C}$ in order to inactivate the enzymes. Half of the RT reaction $(10 \mu \mathrm{l})$ was used for PCR performed in the same buffer with $0.2 \mathrm{mM}$ of each dNTP, 50 pmol of each oligonucleotide $5^{\prime}-3^{\prime}$ and $1 \mathrm{U}$ Taq polymerase. Thirty-five cycles of PCR were done at $94^{\circ} \mathrm{C}$ for $1 \mathrm{~min}, 58^{\circ} \mathrm{C}$ for $1 \mathrm{~min}$ and $72{ }^{\circ} \mathrm{C}$ for $1 \mathrm{~min}$. The primers used were derived from the coding sequences surrounding two introns, allowing cDNAderived PCR products to be distinguished from those which could be derived from the genomic DNA (Table 1).

Chitin synthase extraction and glycerol gradient purification. The mycelium, collected from liquid culture, was homogenized at $4{ }^{\circ} \mathrm{C}$ in extraction buffer $(10 \mathrm{mM}$ Tris/ $\mathrm{HCl} \mathrm{pH} \mathrm{7.4,}$ $500 \mathrm{mM}$ Sorbitol) with a blade homogenizer (Virtis 45) for three 30 s periods. The homogenate was centrifuged at $2000 \mathrm{~g}$ for $10 \mathrm{~min}$ and the supernatant was then centrifuged at $48000 \mathrm{~g}$ for $30 \mathrm{~min}$ at $4{ }^{\circ} \mathrm{C}$. The mixed-membrane fraction $(48000 \mathrm{~g}$ pellet) was resuspended in extraction buffer and the membrane-bound enzymes were solubilized with digitonin $\left(10 \mathrm{mg} \mathrm{ml}^{-1}\right)$ at $4{ }^{\circ} \mathrm{C}$ for $30 \mathrm{~min}$. The detergent extract was centrifuged at $48000 \mathrm{~g}$ for $30 \mathrm{~min}$ and the supernatant was used as the solubilized enzyme preparation. The solubilized enzymes $(2 \mathrm{ml}$ sample) were layered onto a $30 \mathrm{ml} 12-45 \%$ $(\mathrm{v} / \mathrm{v})$ glycerol gradient (in $10 \mathrm{mM}$ Tris $/ \mathrm{HCl} \mathrm{pH} 7 \cdot 4$ ). The gradient was centrifuged for $4 \mathrm{~h}$ at $120000 \mathrm{~g}$ in a Beckman 
Table 1. Synthetic oligonucleotides used for PCR experiments

\begin{tabular}{|c|c|c|}
\hline $\begin{array}{c}\text { Oligo } \\
\text { position* }\end{array}$ & Use & Sequence $\nmid$ \\
\hline $\left.\begin{array}{l}2230 \\
2804\end{array}\right\}$ & CHS fragments for polyclonal antibodies & $\begin{array}{l}5^{\prime} \text { CTGCCATGGCGTATATGTGCAAGGAG 3' } \\
5^{\prime} \text { CGCOI } \\
\frac{\text { BamHI }}{\text { Bam }}\end{array}$ \\
\hline $\left.\begin{array}{l}1330 \\
1715\end{array}\right\}$ & CHS fragments for polyclonal antibodies & $\begin{array}{l}5^{\prime} \text { CGCGGATCCGCACGCCTCCGCGCCCTG } \\
3^{\prime} \\
5^{\prime} \text { CGCGMAIHI } \\
\frac{\text { BamHl }}{}\end{array}$ \\
\hline 1610 & RT-PCR & 5' ACACCTTGGTCCAGC 3' \\
\hline 1977 & RT-PCR & $\begin{array}{l}\text { 5' GCGATCTTGAGCTGC 3' } \\
\qquad \begin{array}{rllll}\text { T } & & & & \\
\text { G } & & & & \\
\text { C } & \text { C } & \text { C } & \text { A }\end{array}\end{array}$ \\
\hline 2163 & PCR & $\begin{array}{l}\text { 5' CTGAAGCTTACAATGTATAATGAG 3' }^{\text {HindIII }} \\
\text { C A } \text { C A A T } \\
\text { 5' GTTCTCGAGTTTGTATTCGAAGTTCTG 3' }_{\text {Xhol }}^{\prime}\end{array}$ \\
\hline
\end{tabular}

*Position of primers was based on the genomic nucleotide sequence presented in Fig. 3.

† Multiple lettering indicates oligonucleotide mixtures. Restriction sites for cloning PCR products are underlined.

SW27 rotor at $4{ }^{\circ} \mathrm{C}$. Fractions $(1.5 \mathrm{ml})$ were collected and assayed for chitin synthase activity.

Chitin synthase assay. Membrane-bound or solubilized enzymes (100 $\mu \mathrm{g}$ protein) were assayed in $10 \mathrm{mM}$ Tris $/ \mathrm{HCl}$ $\mathrm{pH} 7.4$ with $0.5 \mathrm{mM}$ UDP-GlcNAc, $0.5 \mathrm{nCi}(18.5 \mathrm{~Bq})$ UDP$\left[{ }^{14} \mathrm{C}\right] \mathrm{GlcNAc}$ (Amersham, $8.7 \mathrm{GBq} \mathrm{mmol}^{-1}$ ), $20 \mathrm{mM}$ GlcNAc, $10 \mathrm{mM} \mathrm{MgCl}$ and $2.5 \mu \mathrm{g}$ trypsin in a total volume of $200 \mu \mathrm{l}$. The assay mixture was incubated at $25^{\circ} \mathrm{C}$ for $30 \mathrm{~min}$ and the reaction was stopped with $2 \mathrm{ml} 95 \%(\mathrm{v} / \mathrm{v})$ ethanol. The reaction mixture was filtered through a $2.5 \mathrm{~cm}$ diameter glass fibre filter (GF/C, Whatman) and washed successively with $5 \mathrm{ml} 0.5 \mathrm{M} \mathrm{NaOH}, 2 \times 10 \mathrm{ml} 95 \%(\mathrm{v} / \mathrm{v})$ ethanol $/ 1 \mathrm{M}$ acetic acid $(2: 8, \mathrm{v} / \mathrm{v})$ and $2 \times 5 \mathrm{ml} 95 \%(\mathrm{v} / \mathrm{v})$ ethanol. The discs were dried and their radioactivity was measured by scintillation spectrometry (Gay et al., 1993). Protein content was determined according to Bradford (1976).

Chitin synthase entrapment. Product entrapment was carried out according to the method of Duran \& Cabib (1978) using as the enzyme source the most active Chs fraction isolated following glycerol-gradient centrifugation (Gay et al., 1993). The reaction mixture scaled up to $2 \mathrm{ml}$ was incubated as above. After $30 \mathrm{~min}$ of incubation, the chitin-enzyme complexes were sedimented by centrifugation $(10000 \mathrm{~g}$ for $30 \mathrm{~min})$ and the pellet was resuspended in extraction buffer for further analysis.

Production of anti-Chs antibodies. Polyclonal antibodies were raised against part of an amino-terminal region (amino acid positions 8-137) and part of the neutral domain (amino acid positions $270-460$ ) of the product of the CHS2 gene of $S$. monoica. These peptides were expressed in Escherichia coli as fusion proteins with a six-histidine tag (Qiagen). The 375 and $574 \mathrm{bp}$ fragments, encoding 124 and 191 amino acids re- spectively, were amplified by PCR using S. monoica CHS2 as a template and primers containing restriction sites (Table 1). The PCR products were digested and ligated into a $\mathrm{pQE}$ expression vector (Qiagen). The plasmids, pQE60 and pQE30, were introduced into E. coli M15 cells. Expression of fusion proteins was induced by adding $2 \mathrm{mM}$ IPTG and after $2.5 \mathrm{~h}$, cells were harvested and lysed in $6 \mathrm{M}$ guanidine hydrochloride. The recombinant proteins were purified by nickel-chelating chromatography, then analysed by SDS-PAGE. The protein bands were excised, lyophilized and used to immunize rabbits.

Immunodetection of Chs. For immunodetection of Chs2, protein samples from $S$. monoica were separated on a slab gel (5-12.5\%, w/v polyacrylamide) (Laemmli, 1970) and transferred to a Hybond-ECL nitrocellulose membrane (Amersham) according to Towbin et al. (1979). The membranes were blocked for $1 \mathrm{~h}$ with $5 \%(\mathrm{w} / \mathrm{v})$ non-fat dry milk in Trisbuffered saline solution (TBS), $\mathrm{pH} 7 \cdot 4$. After three washes in TBS, blots were incubated for $1 \mathrm{~h}$ at room temperature with polyclonal rabbit antibodies diluted in TBS/milk and washed three times in TBS. Horseradish-peroxidase-conjugated goat anti-rabbit immunoglobulin $G$ (dilution $1: 10000$ ) was used as a second antibody. After three washes in TBS, reactive bands were revealed with the kit 'ECL Western blotting protocols' (Amersham).

\section{RESULTS}

\section{Presence of chitin synthase genes in Oomycetes}

Degenerate oligonucleotides corresponding to the conserved regions of CHS from Sacch. cerevisiae (Bowen et al., 1992) were used for priming PCR amplification of $S$. monoica, A. ambisexualis and P. capsici genomic DNAs 


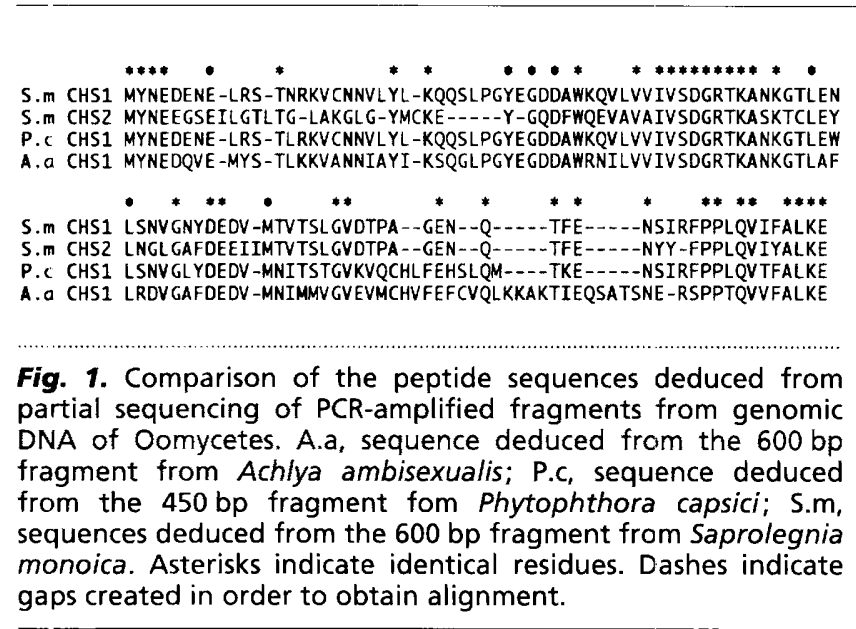

(Table 1). Amplified products derived from the two primers were detected, their size ranging from 450 to 950 bp. The PCR fragments of $600 \mathrm{bp}$ from S. monoica and $A$. ambisexualis and of $450 \mathrm{bp}$ from $P$. capsici were cloned into pUC18 and partial DNA sequences were determined. Analysis of several clones from S. monoica PCR products revealed two ORFs whose predicted amino acid sequences exhibited high similarities to Chs1 and to Chs2 from Sacch. cerevisiae. Comparison of the deduced amino acid sequences of the fragments from $A$. ambisexualis and $P$. capsici revealed homology to the CHS genes from S. monoica (Fig. 1). An overall identity of $35 \%$ was found among the CHS fragments of the three Oomycetes. These results indicate that Oomycetes can also be considered as chitinous organisms. The two CHS PCR-derived fragments from S. monoica have a similar size, resulting in a single band on the gels. The different sizes of the PCR fragments from the other Oomycetes may be due to a different number and/or length of introns in the amplified DNA region.

\section{Evidence for a CHS gene family in S. monoica}

Alignment of the predicted amino acid sequences of the PCR fragments revealed an identity of $50 \%$, indicating the presence of two CHS genes in S. monoica. This was confirmed by Southern analysis of $S$. monoica DNA digested with different restriction enzymes. Hybridization to $\mathrm{Sacl}$-cut DNA with radioactive PCR fragments revealed two bands, of 0.6 and $1 \mathrm{~kb}$ (not shown). From the restriction map of the CHS2 nucleotide sequence, one can predict that the $600 \mathrm{bp}$ CHS2 probe should hybridize to the $1 \mathrm{~kb}$ SacI fragment. Therefore, the remaining band on the blot must be due to hybridization with the CHS1 probe.

S. monoica chromosomes were separated by CHEF electrophoresis and probed with the cloned PCR products. Electrophoretic conditions were such as to allow the separation of the largest chromosomes (i.e. higher than $2 \mathrm{Mb}$ ) whereas the smallest chromosomes appeared as broad bands (Mort-Bontemps \& Fèvre, 1995). Using stringent hybridization conditions, the probe hybridized to chromosomal bands of 4.6 and $3.4 \mathrm{Mb}$, confirming (a)

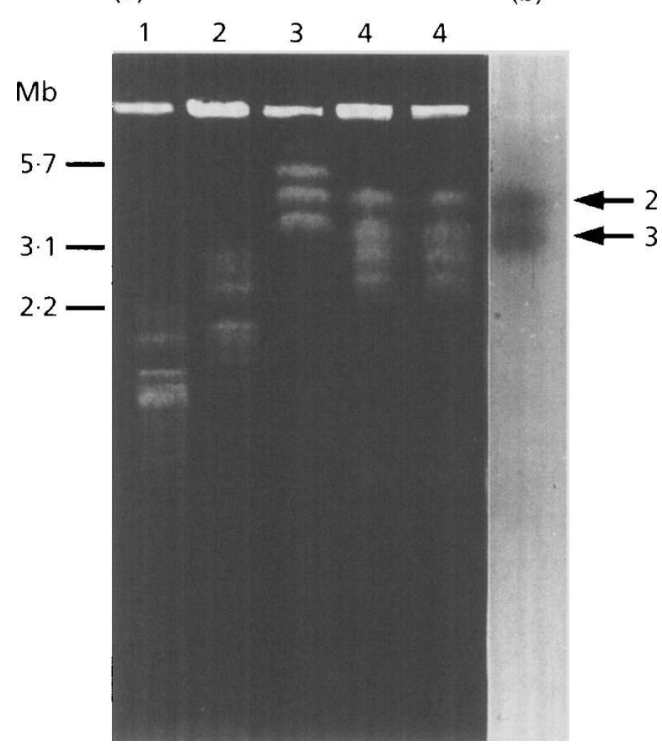

Fig. 2. Chromosomal localization of $S$. monoica $\mathrm{CHS}$ by Southern blot hybridization. (a) Electrophoretic karyotype of S. monoica by CHEF gel electrophoresis stained with ethidium bromide. The electrophoretic conditions for separating the chromosomes were $96 \mathrm{~h}$ ramped pulse from $180 \mathrm{~s}$ to $2700 \mathrm{~s}$ at $50 \mathrm{~V}$ in $0.6 \%(\mathrm{w} / \mathrm{V})$ agarose gels. Chromosomes of $\mathrm{S}$. monoica (lanes 4) were run along with chromosomes of Sacch. cerevisiae (lane 1), Hansenula wingei (lane 2) and Schizosaccharomyces pombe (lane 3). The numbers on the left indicate the size of the chromosome markers in megabase pairs. (b) Southern hybridization of the electrophoretic karyotype transfer. The $600 \mathrm{bp}$ PCR fragment was used to probe the separated chromosomes. The arrows indicate the chromosomal bands 2 $(4.6 \mathrm{Mb})$ and $3(3.4 \mathrm{Mb})$.

the presence of two genes and of a chitin synthase gene family in S. monoica (Fig. 2).

\section{Nucleotide sequence of CHS2 from S. monoica}

The PCR fragment identified as CHS2 by its homology to the Sacch. cerevisiae CHS2 gene was used as a probe to screen a genomic library constructed in the phage iEMBL3. Three positive signals were obtained out of 18000 recombinant phages screened. The phages were isolated and amplified, and their DNA was digested with different restriction enzymes and subjected to Southern analysis. The three clones were overlapping and contained the entire CHS2 gene. A $4.5 \mathrm{~kb}$ segment was sequenced completely on both strands using subclones and oligo primers. The CHS coding region was located by comparison of the predicted amino acid sequence with that of other CHS gene products. Fig. 3 shows the CHS2 nucleotide and deduced amino acid sequences. The sequence revealed an ORF of $2854 \mathrm{bp}$ interrupted by three introns. These intervening sequences were identified on the bases of consensus $5^{\prime}$ and $3^{\prime}$ splice junction sequences. Two introns are situated at the $5^{\prime}$ region of the sequence as in other fungal $C H S$ genes. The third intron is located in the $3^{\prime}$ region as in 
chs 1 of N. crassa and chsB of A. nidulans (Yarden \& Yanofsky, 1991; Yanai et al., 1994). The non-translated $5^{\prime}$ and $3^{\prime}$ regions were analysed for consensus regulatory sequences. The ORF shows a low bias for codon usage, as 60 out of the 61 codons possible are used.

\section{Predicted amino acid sequence of S. monoica CHS2 and comparison with other chitin synthase sequences}

The CHS2 gene encodes a predicted polypeptide of 886 amino acids with a calculated molecular mass of $99 \mathrm{kDa}$ and a pI of $9 \cdot 2$. These values are similar to the calculated pI values and molecular masses of other Chs enzymes.

The amino acid sequence deduced from the introndeleted nucleotide sequence was compared with that of other CHS genes (Fig. 4) by dot matrix computer analysis, revealing a structurally similar region. Comparison of the deduced amino acid sequence with those previously reported showed that similarity was located in the central region of the genes. The amino and carboxy termini showed only isolated conserved amino acids. The most pronounced regions of predicted amino acid identity (spanning amino acids 208-740 in $S$. monoica CHS2 gene) were aligned; 110 residues were conserved among all the sequences and 154 conservative amino acid substitutions were detected. The longest stretches of identical amino acids occurred from residue 207-596 based on the $S$. monoica $\mathrm{Chs} 2$ sequence. In this region, the predicted amino acid sequence of $S$. monoica Chs2 exhibits $28-44 \%$ identity with the predicted polypeptides of chitinous fungi. The identity is higher, ranging from 41 to $77 \%$ among the predicted Chs amino acid sequences of the chitinous fungi (Fig. 4).

An extensive search using the PROSITE database revealed the presence of a motif FEYK(I/L/M)SNIXDK that is specific for enzymes of classes I and II (Bowen et al., 1992). When comparison was extended to class III, this motif was reduced to FEYKXSXXXXK as noticed by Xoconostle-Cazares et al.. (1996). Another motif SWGTKG was also found in all proteins of classes I and II except in those of Ustilago maydis (XoconostleCazares et al., 1996), whose sequences appeared to be truncated in comparison to those of other fungal genes. Genes of the classes III, IV and V (Specht et al., 1996) contained the motif SWG. These motifs could be considered as signatures of the Chs enzyme families (Fig. 5).

Chitin synthases are processive $\beta$-glycosyltransferases that interactively transfer sugar residues to an acceptor forming the carbohydrate chain (Saxena et al., 1995). From hydrophobic cluster analysis of the sequences of several types of glycosyltransferases, we have deduced that two domains are responsible for processivity and have identified the putative catalytic amino acids in each domain (Saxena et al., 1995). The A domain is characterized by two aspartates and they are conserved among all the sequences (corresponding to the residues 291 and 376 of $S$. monoica Chs2). An aspartate and the motif
QXRRW, which are the catalytic residues of the B domain (corresponding to residues 494 and 531-535 of S. monoica Chs2), are also conserved in all the sequences (Fig. 5). These amino acids have also been shown to be essential for the catalytic activity of Sacch. cerevisiae Chs2 (Nagahashi et al., 1995).

Hydrophobicity analysis (Kyte \& Doolittle, 1982) of $S$. monoica Chs 2 predicts a protein with three domains: a hydrophilic region at the amino terminus, a central neutral region and a hydrophobic region at the carboxy terminus containing five potential hydrophobic transmembrane domains. Prediction of the orientation of these transmembrane proteins indicates that the hydrophilic and the neutral domains are in the cytosol. The hydrophobicity plots of the Chs proteins (Fig. 6) were compared following an alignment of the sequences at the residues FEY (at position 420 in the S. monoica Chs 2 sequence). This analysis confirmed the great structural similarity of the different proteins in spite of the weak homology of the deduced amino acid sequences. Regions corresponding to the catalytic domains $\mathrm{A}$ and $\mathrm{B}$ and to the Chs signatures exhibited extensive homologous properties. The large hydrophobic region following the $\mathrm{B}$ domain consists of multiple hydrophobic peaks, indicating that these proteins have a related membrane topology in common. The amino terminus region of all the proteins is different, indicating that this hydrophilic domain is probably not essential for enzymic activity.

\section{Expression of $\mathrm{CHS}$}

Northern hybridizations of total RNA and poly $(\mathrm{A})^{+}$ enriched RNA were done. Unreproducible (or undetectable) signals were obtained, indicating that the CHS transcripts were not abundant. RT-PCR was used to show that the genes are expressed during hyphal growth and protoplast regeneration. Primers (Table 1) were designed to amplify sequences situated on each side of the two introns; these primers allowed the target cDNA and genomic DNA to be size fractionated on agarose gels. Two PCR products, of 234 and $150 \mathrm{bp}$, were revealed whereas no fragment corresponding to the size of the amplified genomic DNA was detected (Fig. 7). To confirm the identity of the ethidium-bromide-stained bands, gels were blotted and probed with a CHS fragment. Signals on the autoradiograms confirmed the results obtained on the stained gels (Fig. 7). These results indicate that two homologous $\mathrm{CHS}$ genes are expressed during the vegetative phase of growth and the cell wall regeneration of the protoplasts. However, one cannot exclude that alternate splicing of introns produces two CHS mRNAs.

\section{Immunodetection of Chs2}

As the entire CHS2 gene or fragments encoding the hydrophobic carboxy terminus could not be expressed in bacterial cells, segments of CHS2 encoding parts of the hydrophilic and neutral domains were PCR amplified (Table 1), and the resulting products Chs2 8-137 
tgtaacgcgctataajgcgtagtagagtaggtatgcgttaaactgagaccgtacatgttcgccatttacctc 72 tgccgctgcaaaccgaacctgagtcaataattaaggagcacgacgcagtggaacaccacgacgaagaatctg 144 tcgctgtggtgcgccgtgtcgctgctcgacgccgcaagcaaaacgcgatcctttgcttccggtagcctgtac 216 tcctgctgaaccactattagggtatacgcgcgcttaaagtttaacgtgaaaataaactcacttacgt 288 caact tatttatgtcctcttggctccaccatcaatgaaaaaatcgagattcogtatgtaatcacaggc 360 gaggaagaaaccgctggagattcggcgacgaaccgcgggacgaggttcgctcatggcatgatgggcttcctg 432 caggtagatgggctggaaactgtccatggtcgtgaggtgatgccgctggctgcgtgagctggcgcgaaaaca 504 tcgctgcttgatccattcctggaaggggccatgattggactgctaagcgcgtgcaccctctctctcatggca 576 cgagagccctcacaagaatgacaagatggtatcaatgatattctggtactttgctaacattaactgaaggaa 648 tctattgtaggagctctgcacatcccccgtatttgtcagcctatcgagagcccaataagtccacaaagcg 720 taacgctgagggtgggttcgtcccaggcaaaaaagagtgggttcttgtgttggaaagcgtctacgtccagc 792 ttcctctttgagcacatttctcttgctgaccatttgctgtaccegtatccaccatcgtgtccacctcgt 864 ggacacaccattgggttcttgtgttcttcaaagttgtccttacgggcatcgatagatctctagaagcggcgc 936 caagtgaggactgcagtaacaattcagaaagcaatccggtaggagcttccacgcattacatgcaagggatga 1008 cagcaacagcaagatgtcccgtcgattgatcgatgctgatctgtgtccttcgccttgcattgtgaagcagtc 1080 tgcttgtcgttcctcgacagggttttggcgctgttttggataaacccacgatttctccgtaatccaaac 1152 ggccgcct act cagtgtatacaaccaagattgccaaacgtttatccccaacgtttgccattaaatcta 1224 tcgaaaaaattgaagtcatacacttgagcgtgtctcacattatattgtttccatttcggtacatttgccaa 1296 gecgacage ATG AGT GAC CAG CTC GAC CTC GCG GCA CGC CTC CGC GCC CTG CGT 1350 $\begin{array}{lllllllllllllllll} & \text { M } & \text { S } & \text { D } & \text { Q } & \text { L } & \text { D } & \text { L } & \text { A } & \text { A } & \text { R } & \text { L } & \text { R } & \text { A } & \text { L } & \text { R } & 15 \\ \text { GAG GGC AAC } & \text { GCC } & \text { GCG } & \text { CCA } & \text { GCC } & \text { GAC } & \text { CCC } & \text { GAG } & \text { ACC } & \text { GCC } & \text { ACC } & \text { CAC } & \text { ACA } & \text { GCC } & \text { TGG } & \text { CCC } & 1404\end{array}$ $\begin{array}{lllllllllllllllllll}E & G & N & A & A & P & A & D & P & E & T & A & T & H & T & A & W & P & 33\end{array}$ GCG CCG CAG TAC CAT CCA CAC TGC CGC CGC TGT ATA CAC AAG AGT CGC TCG AGT 1458 $\begin{array}{lllllllllllllllllll}A & P & Q & Y & H & P & H & C & R & R & C & I & H & K & S & R & S & S & 51\end{array}$ TGG GAG GGA CGT ATG CCA CGG GCA GCC CCG TGC GCC GAG GCC GAG GGG TCC TAC 1512 $\begin{array}{lllllllllllllllllll}\text { W } & E & G & R & M & P & R & A & A & P & C & A & E & A & E & G & S & Y & 69\end{array}$ TCG CAA GTA CCT GTG TGG AAG GAC TCC AAG GAG ACG CGA AGA AGT TAC CTG GAC 1566 $\begin{array}{lllllllllllllllllll}S & Q & V & P & V & W & K & D & S & K & E & T & R & R & S & Y & L & D & 87\end{array}$ GAT GAG CCG ACG CCG CAG CCC CAA TCG CTC ATT AAC ATG GCT AAC ACC TTG GTC 1620 $\begin{array}{lllllllllllllllllll}D & E & P & T & P & Q & P & Q & S & L & I & N & M & A & N & T & L & V & 105\end{array}$ CAG CGC CAA CGT CGA ATC AAT CTT CCG GCG GCA GCA TAC AGC GAA CTT CCG ACC 1674 $\begin{array}{lllllllllllllllllll}Q & R & Q & R & R & I & N & L & P & A & A & A & Y & S & E & L & P & T & 123\end{array}$ GCT GCC CAA CAC CGT CGA GGA GCT TCT GGA CGG CAA GCC AAC gtacgaaggagcgtt 1731 \begin{tabular}{llllllllllllllll}
$A$ & $A$ & $Q$ & $H$ & $R$ & $R$ & $G$ & $A$ & $S$ & $G$ & $R$ & $Q$ & $A$ & $N$ & & \\
\hline
\end{tabular} tcgcctcgtgcagctcgeggtgcagatggagcaag ACG GCG ACC CAG GTG CTG CAA TTA ACT 1793 TGT ACG TGG ACG CTG GCA CGA CGC TCG TCG AAG TC ggtaagcgtgaggtcgaccctcttc 1853

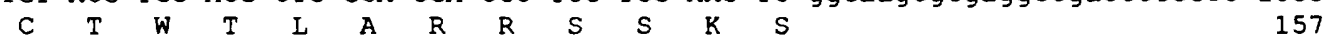
tgcagaagggcatccagcaaaaggcctttgagctcctgcaagT GCC GAG GAG CTC GGC ACG TGG 1917

ATG AAC ACG GTG GCC GAG GAA GCG CGG AAA GCT GCG TTG CCA CCG CAG CTC AAG $\quad$ A $\begin{array}{lllllllllllllllllllllll}M & N & T & V & A & E & E & A & R & K & A & A & \text { L } & \text { P } & \text { P } & \text { Q } & \text { L } & K & 183\end{array}$ ATC GCG CGC ACC AAC GTC CCG ACG GTC GAG CAA GCG TGG AAG GGT CGC ACT CCG 2025 $\begin{array}{lllllllllllllllllll}I & A & R & T & N & V & P & T & V & E & Q & A & W & K & G & R & T & P & 201\end{array}$ CCT TTC CAT GAC GCC GAC GAG TTC CGA CTT ATG CGG TAC ACG GCC GTG GCA ACG 2079 $\begin{array}{lllllllllllllllllll}P & F & H & D & A & D & E & F & R & \text { L } & M & R & Y & T & A & V & A & T & 219\end{array}$ AAA GAC CCG ATC CAG TTC TCG AAC GAC GGA TAC GTG CTC CGG GTG CAC CAG CTA 2133 $\begin{array}{lllllllllllllllllll}K & D & P & I & Q & F & S & N & D & G & Y & V & \text { L } & R & V & H & Q & L & 237\end{array}$ CAT CGG CGC ATC AAG GTC TTC ATC ACA ATC ACT ATG TAC AAC GAA GAA GGC TCA 2187 $\begin{array}{lllllllllllllllllll}H & R & R & I & K & V & F & I & T & I & T & M & Y & N & E & E & G & S & 255\end{array}$ GAG ATC TTG GGC ACG CTC ACT GGT CTC GCC AAG GGC CTC GGG TAT ATG TGC AAG 2241 $\begin{array}{lllllllllllllllllll}E & I & L & G & T & L & T & G & L & A & K & G & L & G & Y & M & C & K & 273\end{array}$ GAG TAT GGC CAG GAT TTT TGG CAA GAA GTT GCT GTG GCT ATC GTC TCA GAC GGC 2295 $\begin{array}{lllllllllllllllllll}E & Y & G & Q & D & F & W & Q & E & V & A & V & A & I & V & S & D & G & 291\end{array}$ CGC ACC AAA GCT AGC AAG ACG TGT CTC GAG TAC CTC AAC GGC CTC GGC GCA TTT 2349 $\begin{array}{lllllllllllllllllll}R & T & K & A & S & K & T & C & L & E & Y & L & N & G & L & G & A & F & 309\end{array}$ GAC GAA GAG ATC ATG ACG GTC ACG AGC CTC GGT GTC GAC ACT CCA GCT GGT GAG 2403 $\begin{array}{lllllllllllllllllll}D & E & E & I & M & T & V & T & S & I & G & V & D & T & P & A & G & E & 327\end{array}$ AAC CAG ACG TTT GAA AAC TAC TTT CCG CCG CTC CAA GTG ATC TAC GCG CTC AAA 2457 $\begin{array}{lllllllllllllllllll}\mathbf{N} & Q & \mathrm{~T} & \mathrm{~F} & \mathrm{E} & \mathrm{N} & \mathrm{Y} & \mathrm{E} & \mathrm{P} & \mathrm{P} & \mathrm{L} & \mathrm{Q} & \mathrm{V} & \mathrm{I} & \mathrm{Y} & \mathrm{A} & \mathrm{L} & \mathrm{K} & 345\end{array}$ GAG AAC AAC GGT GGC AAG CTC AAC TCG CAT CTG TGG TTC TTC AAC GCC TTC AGC 2511 $\begin{array}{lllllllllllllllllll}E & N & N & G & G & K & \text { L } & N & S & H & L & W & F & F & N & A & F & S & 363\end{array}$ GAG CAA TTG AAC CCC AAG TAC ACT GTA CTC GTG GAC GTC GGC ACC ATT CCC GCC 2565 $\begin{array}{lllllllllllllllllll}E & Q & L & N & P & K & Y & T & V & L & V & D & V & G & T & I & P & A & 381\end{array}$ GAA ACG TCC GTT TTC CGC TTG ATC CGC AGC ATG GAG CGC AAC TAC CAG ATC GGC 2619

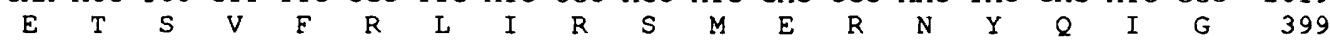
GGC GTT GCG GGG GAG ATT GCA GTC GAA GCA CCT AAC TAC TTC AAT CCT GTC ATT 2673 $\begin{array}{lllllllllllllllllll}G & V & A & G & E & I & A & V & E & A & P & N & Y & F & N & P & V & I & 417\end{array}$ GCC GCA CAG CAC TTC GAG TAC AAG ATC TCA AAT ATC ATG GAC AAG TCG CTT GAG 2727

Fig. 3. For legend see facing page. 
TCC GTC TTT GGT TTT ATC TCG GTG CTC CCG GGG GCC TTC TCA GCC TAC CGG TAC 2781

$\begin{array}{lllllllllllllllllll}S & V & F & G & F & I & S & V & \text { L } & P & G & A & F & S & A & Y & R & Y & 453\end{array}$

GAA GCC ATC CGT GCT GTC AAG GGT GTG GGG CCG CTG CCA GAG TAC TTT AAG AGC 2835

$\begin{array}{lllllllllllllllllll}E & A & I & R & A & V & K & G & V & G & P & L & P & E & Y & F & K & S & 471\end{array}$

CTC ACG TCG ACG ACC AAA GAG CTC GGG CCA TTT CAG GGC AAT ATG TAC CTC GCC 2889

$\begin{array}{llllllllllllllllllll}\text { L } & T & S & T & T & K & E & L & G & P & F & Q & G & N & M & Y & \text { L } & A & 489\end{array}$

GAA GAT CGT ATT TTA TGT TTT GAA TTG CTG GCG CGC AAA CAT AAA CAG TGG ACA 2943

$\begin{array}{lllllllllllllllllll}E & D & R & I & \text { L } & C & F & E & \text { L } & \text { L } & A & R & K & H & K & Q & \text { W } & T & 507\end{array}$

ATG CAC TAT GTC AAG GAC GCG ATC GCC CGC ACT GAC GTT CCC GAG ACG CTC GTA 2997

$\begin{array}{lllllllllllllllllll}M & H & Y & V & K & D & A & I & A & R & T & D & V & P & E & T & \text { L } & \text { V } & 525\end{array}$

GAC CTG ATC AAG CAG GCG CGG CGT TGG CTC AAC GGG TCT TTC TTT GCC GGC CTC 3051

$\begin{array}{lllllllllllllllllll}D & L & I & K & Q & A & R & R & W & L & N & G & S & F & F & A & G & L & 543\end{array}$

TTT GCC ATC GGG ACT TTG GCT GTC TGG AGC CAG AGC TCC CAC ACC ATG TCC CGG 3105

$\begin{array}{lllllllllllllllllll}F & A & I & G & T & I & A & V & W & S & Q & S & S & H & T & M & S & R & 561\end{array}$

AAG CTT GTG TTC ACG TTT CAG TTC TTT TAC CTT GCC CTA CAG AAC CTG CTC AGT 3159

$\begin{array}{lllllllllllllllllll}K & \text { L } & \text { V } & F & \text { T } & \text { F } & \text { Q } & \text { F } & \text { F } & \text { Y } & \text { L } & \text { A } & \text { L } & \text { Q } & \text { N } & \text { L } & \text { L } & \text { S } & 579\end{array}$

TGG TTC CTC TTG AGC AAT TTG TTC CTT ACA TTC TAC TTT GTT TTG ACG CTC GCC 3213

$\begin{array}{lllllllllllllllllll}\text { W } & F & \text { L } & \text { L } & \text { S } & \text { N } & \text { L } & \text { F } & \text { L } & \text { T } & \text { F } & \text { Y } & \text { F } & \text { V } & \text { L } & \text { T } & \text { L } & \text { A } & 597\end{array}$

TTT ACG GAC TCA GCA CCG GCC CTT CTC CAA GCG ATG CTG ACG CTG TAT CTG GCC 3267

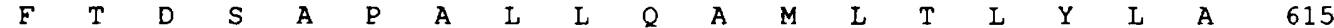

ATT GTC GGT GGC TTG ATT GTC TTT GCG CTC GGG AAC AAG CCC GAA CCT CGG ACG 3321

$\begin{array}{lllllllllllllllllll}I & V & G & G & \text { L } & I & \text { V } & \text { F } & \text { A } & \text { L } & G & \text { N } & \text { K } & \text { P } & \text { E } & \text { P } & \text { R } & \text { T } & 633\end{array}$

GCC AGC TTT TAC CTC TTC AGC TGC CTT TAC ATG GGC ATC ATC ATG ATG CTT GTG 3375

$\begin{array}{lllllllllllllllllll}A & S & F & Y & L & F & S & C & L & Y & M & G & I & I & M & M & L & V & 651\end{array}$

ACC GGC ATT TCC ATC TAC GGC CTT GTC GGC AAG GGC ACA AGC GCT GTG AAA GAC 3429

$\begin{array}{lllllllllllllllllll}T & G & I & S & I & Y & G & \text { L } & \text { V } & G & \text { K } & G & \text { T } & \text { S } & \text { A } & \text { V } & \text { K } & \text { D } & 669\end{array}$

CCA CGG GTG ATC ACG GGG CCC CTT GCA ACT GTA CTG TCT CTG AAG GGG AGC TTG 3483

$\begin{array}{lllllllllllllllllll}P & R & V & I & T & G & P & \text { L } & A & T & V & \text { L } & \text { S } & \text { L } & \text { K } & G & \text { S } & \text { L } & 687\end{array}$

TCG GTG GTG TCG TCA CCT CGG CTT GGC TTG ATC TTC CTC TCT GCC TTC GTC CAT 3537

$\begin{array}{llllllllllllllllllll}S & V & V & S & S & P & R & I & G & L & I & F & \text { L } & \text { S } & \text { A } & \text { F } & \text { V } & \text { H } & 705\end{array}$

GGC GAG TTT AGC ATC CTC CTC AGC GTC ATC CAG TAC TTC TTC ATG CTC CCA ACG 3591

$\begin{array}{lllllllllllllllllll}G & E & F & S & I & L & I & S & V & I & Q & Y & F & F & M & L & P & T & 723\end{array}$

TTT GTG gtatgctatctccctttctctaccttatagtctcataatttccattagaatgtgctggge 3660

F V V 725

atctatgcctacag CAA TTT GCA CAC TTG AGC TGG GGT ACC AAG GGC CTG GAG TCT 3716 $\begin{array}{llllllllllllllll}2 & \text { F } & \text { A } & \text { H } & \text { L } & \text { S } & \text { W } & G & \text { T } & \text { K } & \text { G } & \text { L } & \text { E } & S & & 739\end{array}$

GGG GGC CGC CAC GGA CCA ACG AAA ACC GGC GGC GGT AAA GTC AAG GAA GTC GTC 3770

$\begin{array}{llllllllllllllllllllll}G & G & R & H & G & P & T & K & T & G & G & G & K & V & K & E & V & V & 757\end{array}$

GAG CAG CAG AAG AAG CTC GAA GCC CAA CGC CAG GCC GCG GCT AAG GAG AAA GAA 3824

$\begin{array}{lllllllllllllllllll}E & Q & Q & K & K & \text { L } & E & A & Q & R & Q & A & A & A & K & E & K & E & 775\end{array}$

GAT GTG GAC AAC AGC TTC CGG GCG TTC CGG TCG ACA CTG CTC GCT GTC GTG GCT 3878

$\begin{array}{llllllllllllllllllllll}D & V & D & N & S & F & R & A & F & R & S & T & L & \text { L } & A & V & V & A & 793\end{array}$

CAC GAC CAA CGG CAT TTG GCT CTA CGT TGT GAC GGA CTA CAT GTC GAG CGG GTG 3932

$\begin{array}{lllllllllllllllllll}\mathrm{H} & \mathrm{D} & Q & \mathrm{R} & \mathrm{H} & \mathrm{L} & \mathrm{A} & \mathrm{L} & \mathrm{R} & \mathrm{C} & \mathrm{D} & \mathrm{G} & \mathrm{L} & \mathrm{H} & \mathrm{V} & \mathrm{E} & \mathrm{R} & \mathrm{V} & 811\end{array}$

CTA CTT GAA GGG CCT CAG CTT GTC GTC GGC TTC TTT AAC GTC ATC GTT TCA CGG 3986

$\begin{array}{lllllllllllllllllll}I & L & E & G & P & Q & \text { L } & \text { V } & \text { V } & G & F & F & N & V & I & V & S & R & 829\end{array}$

GCT GCG TTG TAT TTA TTA TCT TGC GCA TCT TTA AGC TAT TCG GCC TTA ACT GCT 4040

$\begin{array}{lllllllllllllllllll}A & A & L & Y & \text { L } & \text { L } & \text { S } & \text { C } & A & \text { S } & \text { L } & \text { S } & \text { Y } & \text { S } & \text { A } & \text { L } & \text { T } & \text { A } & 847\end{array}$

GTG CAA TGG GGG CCA CCC ACG ATA CCT ATG AGC GCA ACC TGC CGG CCG ACT GGG 4094

$\begin{array}{lllllllllllllllllll}V & Q & W & G & P & P & T & I & P & M & S & A & T & C & R & P & T & G & 865\end{array}$

AGA CTC ATT ACA ATG TAC AGA ACC AAG GCG ACG GTC GGG TTG TGG TTG CCC GTG 4148

$\begin{array}{llllllllllllllllllll}R & \text { L } & I & T & M & Y & R & T & K & A & T & V & G & L & \text { W } & \text { L } & \text { P } & \text { V } & 883\end{array}$

CAG AGA GCA TAA acccagcaagccegcgeggcgcctaccaacaagtctaactgcataatacacttgt 4215

$\begin{array}{llll}Q & R \quad * & 887\end{array}$

acgacctcttccattttacgtatcccgattcgtcatgtcaataatttccttgatttacctcgagacggatga 4287 ctcgcacatcacattagtaccgagcattcatagaacttcaacctctgctccattcatgaaggcgtcggaatg 4359 gagcttgacct tcacaggaggctccctcgcgaaattcggaaggttttgtcttaaacctagttttgcgcaat 4431

tcgactatcgcggcatacaaccgcggttcaatagcagatcctctaa

4478

Fig. 3. Complete nucleotide sequence of the $S$. monoica CHS2 gene and flanking regions, and the deduced amino acid sequence of CHS2. Introns are in lower case. The TAA translational stop codon is indicated by an asterisk.

and Chs2 270-460 were cloned into pQE expression vectors. SDS-PAGE analysis of the bacterial lysates revealed that IPTG-induced protein bands were the obviously dominant ones. The molecular masses of the expressed proteins Chs2 8-137 and Chs2 270-460 were 14 and $21 \mathrm{kDa}$, respectively. The Chs2-His tag recom- binant proteins purified with $\mathrm{Ni}$-affinity columns were used to raise rabbit polyclonal antibodies.

The antisera were used for Western blot analysis of total proteins extracted from mycelia. The anti-Chs2 8-137 serum detected two bands of approximately $100 \mathrm{kDa}$ 


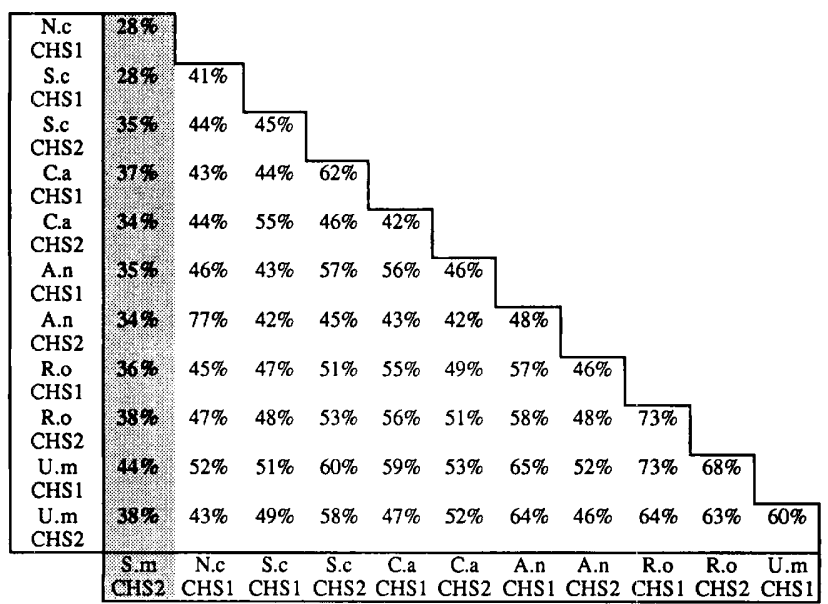

Fig. 4. Comparison of the deduced amino acid sequences of the conserved domains of chitin synthase genes. The percentage of amino acid identity was calculated following alignment of the different sequences to the $S$. monoica sequence from amino acids 208 to 740. S.m, Saprolegnia monoica; N.C, Neurospora crassa; S.c, Saccharomyces cerevisiae; C.a, Candida albicans; A.n, Aspergillus nidulans; R.o, Rhizopus oligosporus and U.m, Ustilago maydis. (GenBank accession numbers U19946; NEUCHT; YSCCHSYNA and YSCCHIS; CACHS1 and CACS2A; ASNCGSA and ASNCHSB; RCHCHS1 and RCHCHS2; UMCHS1GEN and UMCHS2GEN, respectively).

but also showed cross-reaction with other proteins and was not used for further analysis. The anti-CHS2 $270-460$ serum recognized the doublet of $100 \mathrm{kDa}$ and two other bands of about $120 \mathrm{kDa}$. These results confirmed that $S$. monoica contains several chitin synthases (Fig. 8). As the doublet of $100 \mathrm{kDa}$ was recognized by both antisera these proteins may correspond to the products of the two CHS identified following PCR amplification. Using Chs2 270-460 recombinant protein purified from bacterial cells as a standard, the concentration of Chs 2 homologues in the total mycelial extract was estimated to be less than $10 \mathrm{pg}$ per $\mu \mathrm{g}$ of membrane proteins.

Glycerol gradient purification of the solubilized proteins, which has proved efficient in the separation of glycosyltransferases from $S$. monoica (Bulone et al., 1990), was used to partially purify chitin synthase activity. As shown in Fig. 9, chitin synthase activity sedimented as a sharp peak ahead of the bulk of solubilized proteins, and the distribution of the proteins recognized by the anti-Chs $2270-460$ antiserum followed the distribution of the chitin synthase activity. The enzyme activity was partially purified by product entrapment (Gay et al., 1993) and probed with the antiChs2 270-460 antiserum. Among the proteins sedimented with chitin microfibrils, a single polypeptide of approximately $60 \mathrm{kDa}$ was revealed by this technique (not shown). The protein had a smaller molecular mass than the proteins detected from the crude membranes and from the expected size deduced from the CHS2 sequence. This indicates that partial degradation of the enzyme(s) had occurred during the solubilization and purification procedures and that the $60 \mathrm{kDa}$ protein was an active form of chitin synthase. This protein was not detected by the anti-Chs 2 8-137 (not shown); this may

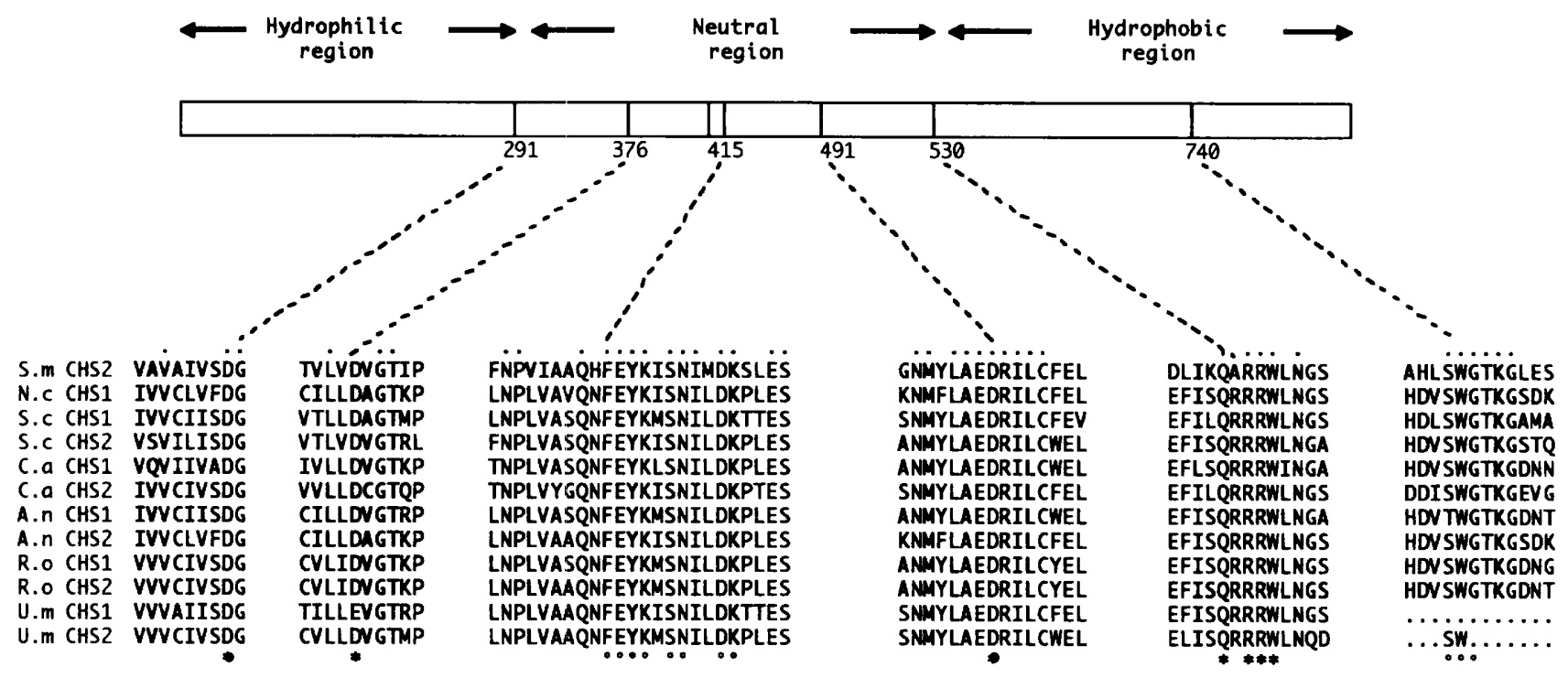

Fig. 5. Comparison of the conserved amino acids in the Chs sequences. The diagram of the native Chs 2 from S. monoica shows the different domains, the position of the catalytic amino acids as determined by Saxena et al. (1995) and the motifs determined as Chs signatures. The catalytic amino acids are indicated by an asterisk and the amino acids of the Chs signatures are indicated by a circle. S.m, Saprolegnia monoica; N.c, Neurospora crassa; S.c, Saccharomyces cerevisiae; C.a, Candida albicans; A.n, Aspergillus nidulans; R.o, Rhizopus oligosporus; U.m, Ustilago maydis. 


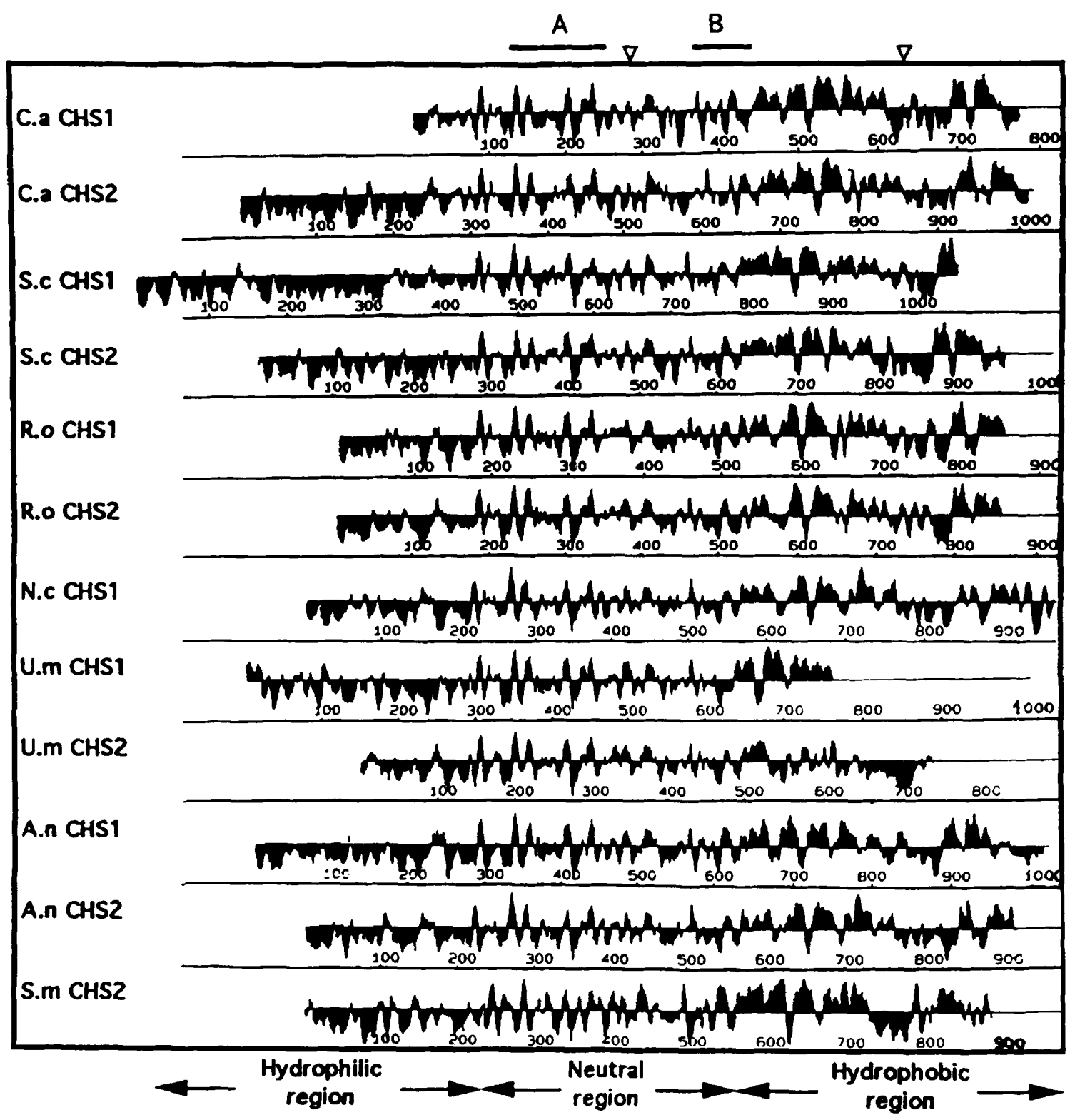

Fig. 6. Comparison of the hydropathy profiles of chitin synthases. Deduced protein sequences were analysed according to Kyte \& Doolittle (1982) and the profiles were aligned to the position of the conserved motif FEY. The localization of the catalytic A and B domains conserved among the glycosyltransferases (Saxena et al., 1995) is indicated at the top. Inverted triangles indicate the position of the amino acid motifs determined as CHS signatures. C.a, Candida albicans; S.C, Saccharomyces cerevisiae; R.o, Rhizopus oligosporus; N.c, Neurospora crassa; U.m, Ustilago maydis; A.n, Aspergillus
nidulans; S.m, Saprolegnia monoica.

reflect the proteolytic cleavage of the hydrophilic domain.

\section{DISCUSSION}

Using degenerate PCR primers, we amplified two conserved regions of chitin synthase genes from the cellulosic fungus $S$. monoica. Similar sequences were also amplified from two other Oomycetes, indicating that the chitin synthase system is widespread in this class of organism. We have cloned and sequenced the CHS2 gene from $S$. monoica and have determined its homology with other CHS genes. The conserved amino acid sequences derived from CHS genes have been useful in the phylogenetic analysis of chitinous fungi, confirming the current taxonomic groupings (Bowen et al., 1992; Mehmann et al., 1994). Compared to other complete predicted Chs polypeptides, Chs 2 from $S$. monoica appears to be well separated (Fig. 10) confirming that Oomycetes are highly divergent from true, chitinous, 
(a)

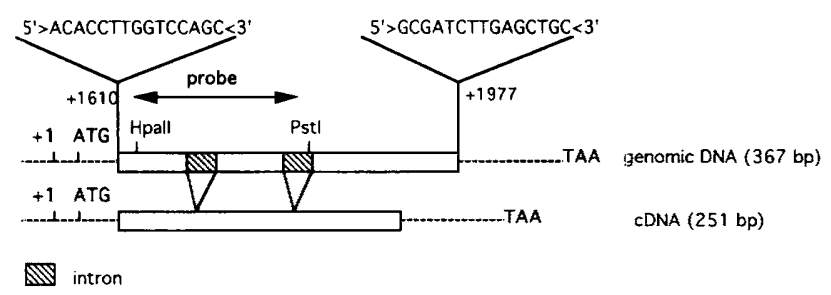

(b)

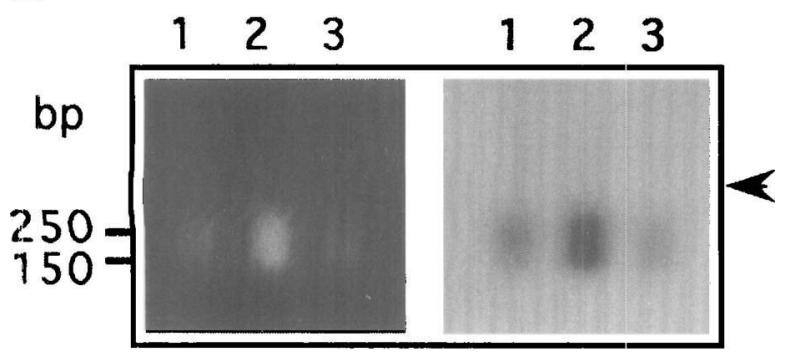

A

B

Fig. 7. Expression of chitin synthase genes of Saprolegnia monoica. (a) RT-PCR strategy. Primers used for RT-PCR (Table 1) were designed from the $5^{\prime}$ and $3^{\prime}$ regions bordering the two introns. An internal fragment was used as a probe to hybridize with the amplified products. (b) Total RNAs were isolated from freshly prepared protoplasts (lane 1), $24 \mathrm{~h}$ regenerated protoplasts (lane 2) and mycelium (lane 3 ). Ethidium bromide staining of the RT-PCR products separated on a $2 \%(w / v)$ agarose gel (A) and hybridization with Hpall-Pstl fragment, used as probe $(B)$. The size of the fragments are indicated on the left. The arrow indicates the predicted size of the genomic fragment delimited by the primers. (a)

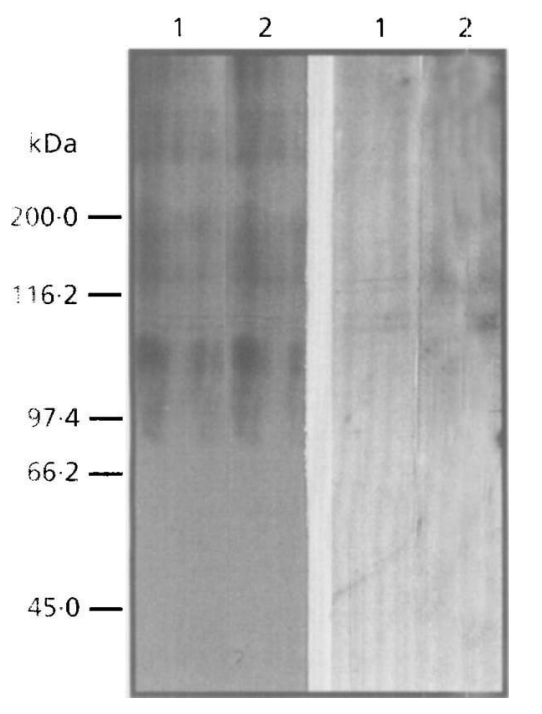

(b)
Fig. 8. Western blots of membrane-bound enzymes from $S$. monoica. Membrane-bound proteins were isolated from mycelial cell-free extracts by centrifugation at $48000 \mathrm{~g}$ for 30 min, separated by SDS-PAGE then transferred onto nitrocellulose and probed with the anti-Chs2 8-137 (a) and with the anti-Chs2 270-460 antiserum (b). Lanes 1 and 2 contained $150 \mu \mathrm{g}$ and $300 \mu \mathrm{g}$ protein, respectively.

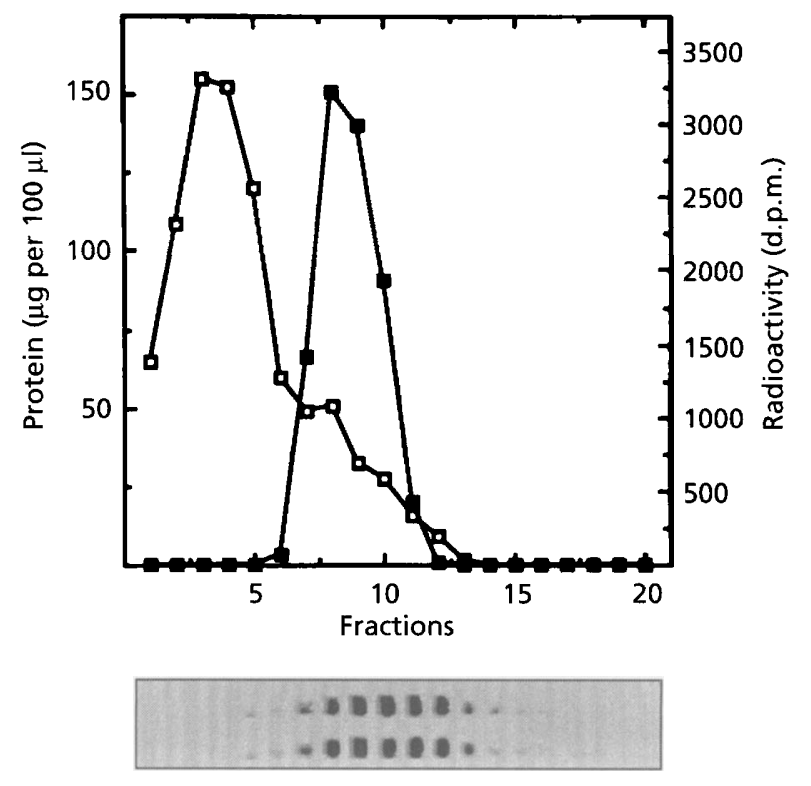

Fig. 9. Glycerol gradient of digitonin-solubilized chitin synthase from S. monoica. Membrane-bound enzymes were solubilized with digitonin, layered onto a glycerol gradient and centrifuged at $120000 \mathrm{~g}$ for $4 \mathrm{~h}$. Fractions were assayed for protein $(\square)$ and chitin synthase activity $(\boldsymbol{\square})$. Proteins from the gradient fractions were deposited onto nitrocellulose and probed with the anti-Chs2 270-460 serum.

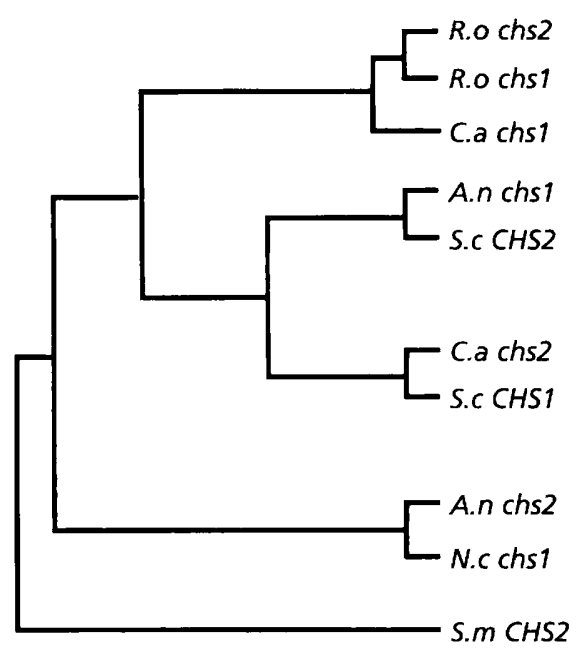

Fig. 10. Maximal parsimony dendrogram showing chitin synthase grouping. The tree was calculated by the program Phylip from amino acid sequences deduced from the chitin synthase genes shown. R.o, Rhizopus oligosporus; C.a, Candida albicans; A.n, Aspergillus nidulans; S.c, Saccharomyces cerevisiae; N.c, Neurospora crassa and S.m, Saprolegnia monoica.

fungi (Cavalier-Smith, 1986). The weak homology between these enzymes was confirmed by immunological probing. An antiserum directed against $S$. monoica Chs2 did not cross-react with proteins from $S a c c h$. 
cerevisiae, and antibodies against the yeast Chs2 enzyme did not recognize the proteins from $S$. monoica (unpublished data).

To date, chitin synthase gene families have been shown to be large in filamentous fungi. In Neurospora crassa, four classes of CHS genes have been identified (Din et al., 1996). Mellado et al. (1995) found that Aspergillus fumigatus has at least six genes encoding various chitin synthases. In S. monoica, the presence of two CHS on two different chromosomes indicates that this enzyme activity is also encoded by a multigene family. We prepared and used polyclonal antibodies against two fragments of Chs 2 to identify the polypeptide in cell free extracts. In addition to a polypeptide of $100 \mathrm{kDa}$, corresponding to the expected size of Chs2, several other bands of higher molecular mass reacted with the antibodies. These may represent other chitin synthases, confirming the existence of a multigene family. Sietsma et al. (1996) have shown that an antibody preparation against Sacch. cerevisiae Chs2 was capable of recognizing several polypeptides in $N$. crassa, which has several CHS genes. Immunodetection of several polypeptides may indicate homologous Chs; however, one cannot exclude that in both cases, other membrane proteins may react with the anti-Chs antibodies.

The topology of S. monoica Chs2 predicted from its sequence is that of a transmembrane protein containing two large cytoplasmic domains, one hydrophilic and one neutral. The putative $N$-glycosylation sites were located in these domains but as glycosyl residues from glycoproteins do not face the cytosol, this indicates that the protein is probably not $N$-glycosylated. In spite of the weak identity with Chs from chitinous fungi, Chs2 from $S$. monoica has striking similarities in size, charge and membrane topology with the enzymes of the other fungi. If the differences in the polypeptide sequences reflect the phylogenetic position of pseudofungi compared to the true fungi, genes of both types of organisms encode functionally equivalent enzymes which synthesize the same product, crystalline $\alpha$-chitin. The presence of motifs conserved among the Chs sequences of these non-related organisms suggests their importance in the organization and/or the catalytic activity of the enzyme. The catalytic amino acids which characterize processive $\beta$-glycosyltransferases (Saxena et al., 1995) and yeast Chs (Nagahashi et al., 1995) were found at conserved positions in all the sequences. Two motifs were identified as specific signatures of Chs.

The antibodies directed against part of the neutral domain containing the catalytic amino acids detected a main protein of $100 \mathrm{kDa}$ in crude membranes, and a polypeptide of $60 \mathrm{kDa}$ entrapped in the chitin synthesized in vitro by detergent-solubilized enzymes. This protein may represent a truncated but still active form of the enzyme. We do not know if this form is the result of the proteolytic activation characterizing chitin synthase activity or the consequence of degradation by endogenous proteases. Recently, Uchida et al. (1996) have shown that trypsin treatment of the membranes from
Sacch. cerevisiae can generate truncated active polypeptides from the $100 \mathrm{kDa}$ zymogenic Chs2, the size of these products ranging from 35 to $75 \mathrm{kDa}$. Therefore a small part, corresponding to the neutral domain of chitin synthases from cellulosic and chitinous fungi is sufficient for catalytic activity.

Two CHS genes were expressed in the mycelium and in regenerating protoplasts of $S$. monoica. Disruption strategies to inactivate $C H S$ as performed in higher fungi are less feasible in $S$. monoica as the fungus is diploid. In order to determine the morphogenetic role of the gene products, we have used antisense RNA to inhibit Chs2 activity; preliminary data show that enzyme activity and hyphal morphogenesis of the transformants are not modified (M. Mort-Bontemps, unpublished data). These results agree with the fact that polyoxin D, a competitive inhibitor of Chs, does not alter hyphal morphology in S. monoica (Bulone et al., 1992). Activity of the CHS2 product seems to be dispensable during hyphal growth. However, it is still possible that additional genes are present in this organism and that other chitin synthase activities less sensitive to the inhibitor are involved in morphogenesis.

In conclusion, the results presented in this paper confirm clearly, and complement our previous data (Bulone et al., 1992), that chitin can no longer be considered as a discriminative character between Oomycetes and higher fungi. They also indicate that chitin biosynthesis in $S$. monoica is mediated by multiple chitin synthases, encoded by a multigene family as in chitinous fungi. In spite of their divergent evolution, pseudofungi and fungi have evolved with conserved chitin synthase systems.

\section{ACKNOWLEDGEMENTS}

We thank V. Bulone for the construction of the genomic library of $S$. monoica in phage $\lambda E$ EBL3, H. Sietsma for providing the antiserum raised against the Sacch. cerevisiae Chs2 and J. Silver for providing genomic DNA of A. ambisexualis. The help with computer analysis of the sequences and discussions with G. Deléage (IBCP, Université LYON 1) are very much appreciated. This work was supported by grants from the CNRS and the Universite Claude Bernard (UMR5534). M.M.-B. was a recipient of a Doctoral MRES Fellowship.

\section{REFERENCES}

Barr, D. J. S. (1992). Evolution and kingdoms of organisms from the perspective of a mycologist. Mycologia 84, 1-11.

Bartnicki-Garcia, S. (1968). Cell wall chemistry, morphogenesis and taxonomy of fungi. Annu Rev Microbiol 22, 87-108.

Bartnicki-Garcia, S., Bracker, C. E., Reyes, E. \& Ruiz-Herrera, J. (1978). Isolation of chitosomes from taxonomically diverse fungi and synthesis of chitin microfibrils in vitro. Exp Mycol 2, 173-192.

Bowen, A. R., Chen-Wu, J. L., Momany, M., Young, R., Szaniszlo, P. J. \& Robbins, P. W. (1992). Classification of fungal chitin synthases. Proc Natl Acad Sci USA 89, 519-523.

Bradford, M. (1976). A rapid and sensitive method for the quantitation of microgram quantities of protein utilizing the principle of protein-dye binding. Anal Biochem 72, 248-254. 
Bulawa, C. E. (1993). Genetics and molecular biology of chitin synthesis in fungi. Annu Rev Microbiol 47, 505-534.

Bulone, V., Girard, V. \& Fèvre, M. (1990). Separation and partial purification of $1,3 \beta$ glucan and 1,4 $\beta$ glucan synthase from Saprolegnia. Plant Pbysiol 94, 1748-1755.

Bulone, V., Chanzy, H., Gay, L., Girard, V. \& Fèvre, M. (1992). Characterization of chitin and chitin synthase from the cellulosic cell wall fungus Saprolegnia monoica. Exp Mycol 16, 8-21.

Cabib, E. (1987). The synthesis and degradation of the chitin. Adv Enzymol Relat Areas Mol Biol 59, 59-101.

Cabib, E., Silverman, S. J., Sburlati, A. \& Slater, M. L. (1989). Chitin synthesis in yeast (S. cerevisiae). In Biochemistry of Cell Walls and Membranes in Fungi, pp. 31-41. Edited by P. J. Kuhn, A. P. J. Trinci, M. J. Jung, M. W. Goosey \& L. G. Copping. Berlin \& Heidelberg: Springer.

Cavalier-Smith, T. (1986). The kingdom Chromista: origin and systemics. In Progress in Phycological Research, vol. 4, pp. 309 347. Edited by F. E. Round \& D. J. Chapman. Bristol: Biopress. Cavalier-Smith, T. (1987). The origin of fungi and pseudofungi. In Evolutionary Biology of the Fungi, British Mycological Society Symposium 11, pp. 339-353. Edited by A. D. M. Rayner, C. M. Brasier \& D. Moore. London: Academic Press.

Chirgwin, J. M., Przybila, A. E., McDonald, R. J. \& Rutter, W. J. (1979). Isolation of biologically active ribonucleic acid from sources enriched in ribonuclease. Biochem 18, 5294-5299.

Din, A. B. \& Yarden, O. (1994). The Neurospora crassa chs-2 gene encodes a non-essential chitin synthase. Microbiology 140 , 2189-2197.

Din, A. B., Specht, C. A., Robbins, P. W. \& Yarden, O. (1996) chs-4, a class IV chitin synthase gene from Neurospora crassa. Mol Gen Genet 250, 214-222.

Duran, A. \& Cabib, E. (1978). Solubilization and partial purification of yeast chitin synthase. J Biol Chem 253, 4419-4425.

Gay, L., Chanzy, H., Bulone, V., Girard, V. \& Fèvre, M. (1992). Chitin pleomorphism in the cellulosic cell wall fungus Saprolegnia. FEMS Microbiol Lett 100, 405-410.

Gay, L., Chanzy, H., Bulone, V., Girard, V. \& Fèvre, M. (1993). Synthesis in vitro of crystalline chitin by a solubilized enzyme from the cellulosic fungus Saprolegnia monoica. J Gen Microbiol 1.39, 2117-2122.

Gold, S. E. \& Kronstad, J. W. (1994). Disruption of two genes for chitin synthase in the phytopathogenic fungus Ustilago maydis. Mol Microbiol 11, 897-902.

Gunderson, J. H., Elwood, H., Ingold, A., Kindle, K. \& Sogin, M. L. (1987). Phylogenetic relationships between chlorophytes, chrysophytes and oomycetes. Proc Natl Acad Sci USA 84, 5823-5827.

Karuppayil, S. M., Peng, M., Mendoza, L., Levins, T. A. \& Szaniszlo, P. J. (1995). Identification of the conserved coding sequences of three chitin synthase genes in Fonsecaea pedrosoi. $J$ Med Vet Mycol 34, 117-125.

Kyte, J. \& Doolittle, R. F. (1982). A simple method for displaying the hydropathic character of a protein. J Mol Biol 157, 105-132. Laemmli, U. K. (1970). Cleavage of structural proteins during the assembly of the head of bacteriophage T4. Nature 227, 680-685.

Machlis, L. (1953). Growth and nutrition of watermolds in the subgenus Euallomyces. II. Optional composition of the minimal medium. Am J Bot 40, 449-460.

Mehmann, B., Brunner, I. \& Braus, G. H. (1994). Nucleotide sequence variation of chitin synthase genes among ecto- mycorrhizal fungi and its potential use in taxonomy. Appl Environ Microbiol 60, 3105-3111.

Mellado, E., Aufauvre-Brown, A., Specht, C. A., Robbins, P. W. \& Holden, D. W. (1995). A multigene family related to chitin synthase genes of yeast in the opportunistic pathogen Aspergillus fumigatus. Mol Gen Genet 246, 353-359.

Mort-Bontemps, M. \& Fèvre, M. (1995). Electrophoretic karyotype of Saprolegnia monoica. FEMS Microbiol Lett 131, 325-328.

Nagahashi, S., Sudoh, M., Ono, N., Sawada, R., Yamaguchi, E., Uchida, Y., Mio, T., Takagi, M., Arisawa, M. \& Yamada-Okabe, H. (1995). Characterization of chitin synthase 2 of Saccharomyces cerevisiae. Implication of two highly conserved domains as possible catalytic sites. J Biol Chem 270, 13961-13967.

Raeder, U. \& Broda, P. (1985). Rapid preparation of DNA from filamentous fungi. Lett Appl Microbiol 1, 17-20.

Sanger, F., Nicklen, S. \& Coulson, A. R. (1977). DNA sequencing with chain-terminating inhibitors. Proc Natl Acad Sci USA 74, 5463-5467.

Sambrook, J., Fritsch, E. F. \& Maniatis, T. (1989). Molecular Cloning: a Laboratory Manual, 2nd edn. Cold Spring Harbor, NY: Cold Spring Harbor Laboratory.

Saxena, I. M., Brown, R. M., Fèvre, M., Geremia, R. A. \& Henrissat, B. (1995). Multidomain architecture of $\beta$-glycosyl transferase: implications for mechanism of action. J Bacteriol 177, 1419-1424.

Shaw, J. A., Mol, P. C., Bowers, B., Silverman, S. J., Valdivieso, M. H., Duran, A. \& Cabib, E. (1991). The function of chitin synthases 2 and 3 in the Saccharomyces cerevisiae cell cycle. J Cell Biol 114, 111-123.

Shuldiner, A. R., Tanner, K., Moore, C. A. \& Roth, J. (1991). RNA template-specific PCR: an improved method that dramatically reduces false positives in RT-PCR. Biotechniques 11, 760-763.

Sietsma, J. H., Din, A. B., Ziv, V., Sjollema, K. A. \& Yarden, O. (1996). The localization of chitin synthase in membranous vesicles (chitosomes) in Neurospora crassa. Microbiology 142, 15911596.

Specht, C. A., Liu, Y., Robbins, P. W., Bulawa, C. E., lartchouk, W., Winter, K. R., Riggle, P. J., Rhodes, J. C., Dodge, C. L., Culp, D. W. \& Borgia, P. T. (1996). The chs $\mathrm{D}$ and chsE genes of Aspergillus nidulans and their roles in chitin synthesis. Fungal Genet Biol 20, 153-167.

Towbin, H., Staehelin, T. \& Gordon, J. (1979). Electrophoretic transfer of proteins from polyacrylamide gels to nitrocellulose sheets: procedure and some applications. Proc Natl Acad Sci USA 76, 4350-4354.

Uchida, Y., Shimmi, O., Sudoh, M., Arisawa, M. \& Yamada-Okabe, H. (1996). Characterization of chitin synthase 2 of Saccharomyces cerevisiae. II. Both full size and processed enzymes are active for chitin synthesis. J Biochem 119, 659-666.

Xoconostle-Cazares, B., Leon-Ramirez, C. \& Ruiz-Herrera, J. (1996). Two chitin synthase genes from Ustilago maydis. Microbiology 142, 377-387.

Yanai, K., Kojima, N., Takaya, N., Horiuchi, H., Ohta, A. \& Takagi, M. (1994). Isolation and characterization of two chitin synthase genes from Aspergillus nidulans. Biosci Biotechnol Biochem 58, 1828-1835

Yarden, O. \& Yanofsky, C. (1991). Chitin synthase 1 plays a major role in cell wall biogenesis in Neurospora crassa. Genes Dev 5 , $2420-2430$

Received 4 November 1996; revised 28 January 1997; accepted 3 February 1997. 